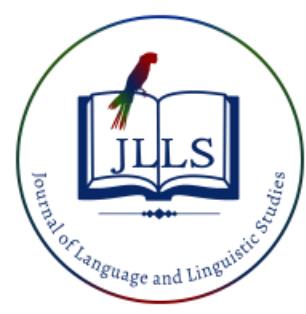

Available online at www.jlls.org

JOURNAL OF LANGUAGE AND LINGUISTIC STUDIES

ISSN: 1305-578X

Journal of Language and Linguistic Studies, 17(4), 1984-1997; 2021

\title{
The effect of microteaching technique of Iraqi EFL student teachers on their teaching performance and attitudes
}

\author{
Ali Abdulhussein Sagban ${ }^{\text {al }}$ iD, Hisham Adnan AlMumar ${ }^{\text {b }}$ iD, Zaid Fouad Hashim c iD \\ ${ }^{a}$ Al-Furat Al-Awsat Technical University (ATU), Iraq \\ ${ }^{b}$ College of Physical Planning/ University of Kufa, Iraq \\ ${ }^{c}$ Al-Furat Al-Awsat Technical University (ATU), Iraq
}

\section{APA Citation:}

Sagban, A.A., AlMumar, H.A., Hashim, Z.F. (2021). The effect of microteaching technique of Iraqi EFL student teachers on their teaching performance and attitudes. Journal of Language and Linguistic Studies, 17(4), 1984-1997. Doi: 10.52462/jlls. 144

Submission Date:11/06/2021

Acceptance Date:28/09/2021

\begin{abstract}
Microteaching is a significant strategy in teacher education programs for giving student teachers opportunities to practice their teaching techniques. This study aims at investigating how using microteaching affects the teaching performance and attitude of Iraqi EFL student teachers. For this purpose, 30 Iraqi EFL student teachers were selected and then randomly assigned to two groups:control and experimental, 15 in each. To collect the data of the study, two instruments were used. The first one is a checklist used to measure student teachers' teaching performance; while the other is a questionnaire used to measure their attitudes toward microteaching. The study hypotheses state that the learners' mean scores in the post-administration of teaching performance checklist and microteaching attitude questionnaire for the two groups were not significantly different. The findings revealed that performance of the experimental group was significantly higher than that of the control group and that using the microteaching method was more rewarding than the traditional tutoring. Furthermore, microteaching as a training method was also viewed favorably by the participants in the experimental group.
\end{abstract}

Keywords: Microteaching technique; EFL Student teachers; Teacher Training; Teaching performance; Attitudes

\section{Introduction}

The development of any country depends completely on education. Various factors can influence improving education and the most essential one is the teacher. The teacher plays a vital role in bringing about and shaping behavioral changes in learners. Thus, teacher's primary role in school may be to guide and direct students while still giving information. The instructor in this job encourages students to form positive relationships and develops their skills. As a result, it's critical to train instructors to be experts in their fields to be competent in their discipline (Liston, Whitcomb \& Borko, 2006).

Noticing and accomplishment in schools, according to Kuran (2009), are crucial steps in enhancing pre-service teachers' realization. These strategies can be used by pre-service teachers to practice teaching information and skills in a genuine classroom situation. Yet, for pre-service teachers who have never taught before, the behaviors in teaching practices may seem rigid and puzzling.

\footnotetext{
${ }^{1}$ Corresponding author:

E-mail address: dw.ali3@atu.edu.iq
} 
Thus, the microteaching approach and other similar techniques are being implementedin for the sake of satisfying the wants of teacher education programs and overcoming difficulties that develop. (Güney, 2008). It has been pointed out that effective microteaching provides a significant opportunity to improve the teaching abilities of student teachers in their practicum. To be more specific, microteaching serves as a testing ground for teaching practice (Can,2009).

Research studies on second/foreign language teaching have consistently emphasized the importance of using the microteaching technique in enhancing and developing the student teachers' competencies. It has been acknowledged that the microteaching technique provides student teachers with important opportunities to improve successful teaching methods and aids in the promotion of real-world teaching experiences (Ambili, 2013). In addition, Çelik (2001) states that microteaching's core skills, such as presentation and reinforcement, assist new teachers in learning the art of teaching. Furthermore, microteaching facilitates the transition from theory to practice.Thus, the current study tries to use micro-teaching -as one of the most effective techniques- to help Iraqi EFL student teachers improve their teaching performance. Moreover, the study examines the effect of using this technique on student teacher's attitudes. In particular, we need answers to the following research questions:

1. What is the effect of using the microteaching technique on the teaching performance of Iraqi EFL student teachers?

2. What is the effect of using the microteaching technique on Iraqi EFL student teachers' attitudes?

\section{Research Hypotheses}

Based on the research questions above, the null hypotheses were formulated as follows:

1. Using the microteaching techniquedoes not significantly affect the teaching performance of Iraqi EFL student teachers.

2. Using the microteaching technique does not significantly affect Iraqi EFL student teachers' attitudes.

\section{Literature Review}

\section{The Significance of Microteaching Technique}

Microteaching is an instructional approach used in teacher professional development. (Adewoyin, 2007). Jebungei (2017) defines micro teaching asa process in which novice teachers gain knowledge of the teaching fundamentals to know what they need before going out into the classroom to practice teaching. It is practical experience that prepares student teachers for the obstacles they will face in the classroom.

According to Otsupius (2014), microteaching is a training methodology that allows student teachers to learn teaching skills. It makes use of real-life teaching situations to help students develop their skills, gaining a greater understanding of the art of teaching and demonstrating a significant reduction in the complexities of teaching in terms of students'number in a class, the subject variety, and the time (Çelik, 2001; Gürses, Bayrak, Yalçn, Açkyldz \& Doar, 2005).

Similarly, Ambili (2013) states that microteaching preserves to be an effective approach to improve abilities and build skills and trust, as well as to try out different lecturing/tutoring methods and offering positive feedback. In addition, trainers are presented with a chance to observe and comment on their peers' performances. Moreover, it is thought to be a method for teacher training in which teaching habits and skills can be practiced in small groups with the help of video tapes. It's a good time 
to learn about students' needs and desires and develop one's own repertory of teaching methods. It is a tried and true approach in support of novice teachers to expand their overall instructional competenc. Görgen (2003) argues that microteaching can equip the pre-service teachers with opportunity of shaping a tryout condition for instructing activities and gaining experience in creating lesson plans, determining teaching objectives, testing students' interest, talking in front of a class, posing queries, effectively administrating time, and evaluation procedures.

In addition, teaching practice, according to Owosu and Brown (2014), is a vital move in the professional progress of teachers because it allows novice teachers to put their classroom knowledge and skills to be used in authentic situations. According to Mahuta (2009), novice teachers are predictable to acquire the various competencies during the course of their training practice such as attaining teaching skills, using them in a practical environment, changing the focus and playing a central role throughout teaching and learning, presenting attitudinal change, and demonstrating and manipulate teaching abilities and techniques, as well as the practicalization of teaching in an observable and measurable milieu.

In conclusion, according to some researchers, activities of microteaching assist student teachers in overcoming anxiety, hesitation, and apprehension, increasing professional engagement, raising awareness about the teaching profession, being effective in teaching skills, learning how to interact with students, and gaining expertise in measurement and evaluation, gaining experience in measuring and evaluation, and becoming qualified at drawing students' attention to the lesson, consuming time professionally, using instructional technology, and managing classroom (Arends, 2000; Kpanja, 2001; Fernandez \& Robinson, 2006; Ogeyik, 2009; Fernandez, 2010).

\section{Phases of Microteaching}

Microteaching involves different stages of skill acquisition. A microteaching cycle includes teaching, reviewing and reflecting, and re-teaching. The teaching stage of a microteaching lesson begins with presenting a lesson by student teachers. While teaching, they are observed by their classmates and instructor; the lesson is then discussed to assess student teachers' performance; and finally, during the re-teaching step, student teachers re-teach the lesson based on suggestions given during the discussion and evaluation stages. (Arends, 2000).

The knowledge acquisition phase, skill acquisition phase, and transfer phase are the three steps of microteaching (Majoni, 2017; Ambili, 2013). The pre-active phase is referred to as the information acquisition phase. Beginner teachers learn about the abilities and their components through orientation, seminars, conversations, lessons, diagrams, and other types of learning. They gain an understanding of the skill significance as well as the situations that are valuable within teaching and learning process. The second phase is the skill acquisition phase. It's an immersive process in which student teachers must plan micro-lessons based on expert demonstrations. In the microteaching cycle, student teachers practice the skills and keep working until they achieve mastery. The feedback is provided to change the actions of the student teachers in the preferred direction. The transfer stage is the final one of microteaching. It is known as the post-active phase. When the student teachers have learned and command each of the skills, they combine them all and move on to real classroom teaching.

For Peker (2009), Planning is the first step in the microteaching cycle. The process includes planning, teaching, criticizing, re-planning, re-teaching, and re-criticizing. Pre-service teachers must design a format of work, instructional materials, and a lesson plan as part of their preparation. Psychological readiness of the pre-service teacher is required.Pre-service teachers plan and present micro-lessons to real students during the teaching stage (a micro class). These lessons are often recorded using video cameras or portable receivers. After that, the pre-service teachers would see a 
video of the teaching session. Micro lessons are examined, discussed, analyzed, and evaluated during the critique stage (Çelik, 2001). The critiques and suggestions of the guiding teacher and their colleagues are taken into consideration by novice teachers. The lesson plan was updated, and preservice teachers re-taught micro-lessons to the same audience. The second micro lessons are also recorded using video cameras or portable receivers. After watching the second micro lesson, the teacher and peers share their reviews of the first and second micro lessons, emphasizing on the worst and greatest features of each. Finally, the microteaching practice's process allows pre-service teachers are allowed, through microteaching practice's process, to assess their strengths and weaknesses, as well as try to enhance weak aspects (Ekşi, 2012).

According to Dweikat (2010), microteaching is divided into four stages: The trainee learns a specific teaching skill in the first step, next implement it in a small part of a lesson; the trainee then receives feedback from the supervisor on the importance of his or her presentation; and finally, the trainee get feedback from classmates and supervisor.

Ananthakrishnan (1993) identified nine stages in the microteaching process: Lesson Planning: entails having specific goals and a well-thought-out sequence. Set induction: is a technique for capturing students' awareness at the starting point of a lecture. Presentation: explaining, narrating, including relevant diagrams and examples, and expected repetition where possible are all part of the presentation. Stimulus variation: gestures, motions, concentration, quiet, changing sensory channels, and other techniques are used to keep students from becoming bored.

Usage of audio-visual aids correctly. Reinforcement: recognizing student challenges, listening, and facilitating student engagement and response are all examples of reinforcement.

Questioning. : fluency in posing, passing, and adjusting questions are all aspects of questioning.

Silence and nonverbal indications (body language). Closure: at the end of a teaching session, a means of emphasizing the importance of what has been learnt, its relationship to past learning, and its contribution to future learning.

\section{Microteaching and Attitudes}

In general, attitude is a state of readiness influenced by experience that affects a person's response to stimuli. A person's attitude is made up of three parts: affective, behavioral, and cognitive, and it can be, and can thus serve as a standard for individual behavior (Feldman, 2003). Attitudes are judgments; positive or negative remarks about objects, people, or events( Ustuner, Demirtas, and Comert ,2009).

Al-Zaidiyeen, Mei, \& Fook (2010), People's responses to a specific situation are influenced by their attitudes. The attitude of the teacher is a critical factor in the implementation of new concepts and approaches to teaching in the classroom. As a result, the most crucial determinants of any program's success is attitude (Bichi, Embong \& Mamatn, 2015).

Al-Zaidiyeen, Mei and Fook (2010) found that people's attitudes play a big role in how they respond to different circumstances. In the implementation of innovative concepts and experimental approaches to teaching in the classroom, the teacher's attitude is a critical variable. As a result, one of the most important determinants of any program's effectiveness is attitude.

The teacher's attitude is influenced by a variety of factors, including the teacher's domestic climate, family history, social background, values, and educational institutions. School status, school facilities, school safety conditions, social and professional status are all important factors in influencing teachers' attitudes (Barros \& Elia,1998).

Another aspect that influences one's attitude is experience. This is also applicable in the field of education. The teaching experience of the teacher has a significant impact on attitudes. The attitude of 
the teacher toward the subject and the students has a great impact on the students' ability to learn. (Suja, 2007).

Various studies have shown a favorable attitude toward microteaching. Amobi (2005) analyzed pre-service teachers' reflective outputs from a second microteaching session and and concluded that microteaching was a good and meaningful learning experience for them. During a second microteaching session, student teachers concluded that microteaching was a constructive and worth while learning experience for them.

Fernandez and Robinson (2006) investigated the experiences of student teachers at Florida State University, finding that the ability to put the pedagogical principles they learned in class into practice was extremely beneficial. They stated that they had spent a lot of time discussing theories and that they needed the opportunity to put the theories into practice and receive feedback on their real performance. Finally, Finally, the treatment subjects recognized the value of perspectives and feedback exposed by others in improving their teaching abilities, as well as the importance of reflection in the development of teaching skills. Ogeyik (2009), another study looked into the benefits and drawbacks of microteaching among student instructors at Trakya University in Turkey, and concluded that incorporating such a technique into a teacher-training program could help students develop successful teaching strategies and reflective practices

\section{Methodology}

\section{Research Design}

The method used in this research was a quantitative one. This designing method involves selecting two groups randomly and assigning them into experimental and control groups. Both groups were subjected to pre-administration of the teaching performance checklist. Only the experimental group received the independent variable (microteaching technique). The traditional method of teaching was used with the control group. To measure the dependent variable (teaching performance), both groups were undergone to a post-administrationof the teaching performance checklist. The results of the preadministered were then compared to those of the post-administered for both groups. If the experimental groups' scores vary significantly from the control groups' scores, the variance is attributed to the independent variable.

\section{Participants}

Thirty students, in theirfourth year before graduation, were involved in this study. They were selected randomly from English Department at the College of Education /Al-Qadisiyah, University for the academic year 2017- 2018. Then, they were separated into two groups, each with 15 . The experimental group (using the microteaching technique) and the control group (using the traditional method of teaching). Only the experimental group enrolled in a course of microteaching technique which lasted for four weeks, two days a week, two hours a day. The theoretical course involved a microteaching technique in which the participants were taughtby the authors how to introduce and carry out a lesson on any required topic including basic components like classroom instruction, teaching practice, and classroom management. After finishing the theoretical course, the experimental group subjects were required to introduce mini-lectures of a specific topic. One thing to be kept in mind is that the groups of the study (control and experimental) were equalized. The equivalence of the two groups was checked according to their age, their intelligence level. Also, their teaching performance was checked via the checklist constructed for this purpose. Table 1 shows that the two groups are equivalent in teaching performance before the application of the experiment. 
Table 1. Statistics for the Control and Experimental Groups of the Pre-administration of the Teaching Performance Checklist

\begin{tabular}{|c|l|c|c|c|c|c|c|c|}
\hline \multirow{2}{*}{ Variable } & \multicolumn{1}{|c|}{ Group } & No. & Mean & SD & \multicolumn{2}{|c|}{ t-value } & \multirow{2}{*}{$\begin{array}{c}\text { Level } \\
\text { of sig. }\end{array}$} \\
\cline { 5 - 7 } & & & & & Calculated & Tabulated & \\
\hline $\begin{array}{c}\text { Teaching } \\
\text { Performance }\end{array}$ & Control & 15 & 1.6472 & 0.43833 & \multirow{2}{*}{1.454} & 1.76131 & 14 & 168 \\
\cline { 2 - 6 } & Experimental & 15 & 1.7187 & 0.56579 & & \\
\hline
\end{tabular}

\section{Instrumentation}

Two instruments were constructed by the researchers to collect the required data of the study. The first one is a checklist used to measure student teachers' teaching performance; while the other is a questionnaire used to measure their attitudes toward microteaching. The checklist is used to document notes about student teachers' teaching performance while presenting mini-lesson using the microteaching technique. The checklist involves 41 items. The items are distributed on 11 standers components. The rating scale is a five-point scale with the attributes: unacceptable, poor, satisfactory, good, and excellent and the corresponding values; 1, 2, 3, 4, and 5 respectively (see Appendix I).

A microteaching attitude questionnaire is the second tool used to assess participants' attitudes toward microteaching (see Appendix II). There are a total of 27 items in the final version of the questionnaire. On a five-point scale, these items are rated as follows: strongly agree, agree undecided, disagree, and disagree strongly.

The checklist was checked by experts in the English language and ELT for suitability. Alpha Cronbach's was used to measure the pre and post checklist administration reliability. The scores were 94 and 96, respectively, suggesting that the administrations were reliable. The same procedure was followed with the microteaching attitude questionnaire. A jury of experts reviewed it to decide its appropriateness. They agreed that the questionnaire is appropriate, except for a few minor changes that have been proposed. The reliability of the microteaching attitude questionnaire was assessed using Alpha Cronbach's coefficient. An internal consistency coefficient is 0.81 , which means that it is reliable.

\section{Procedures}

The author (one of the researchers) gave instructions to both classes. For both groups, the lessons were scheduled as two sessions per week. The main procedures followed in this study are:

1. Choosing a representative sample that will be split into two groups: experimental and control.

2. Constructing a checklist of observation based teaching performance standards,

3. Constructing a questionnaire finding out student-teachers attitudes toward microteaching technique.

4. Applying the questionnaire to the experimental group,

5. Using the microteaching technique with EFL student teachers with the experimental group, while those of the control group received traditional instruction.

\section{Final Administration}

Both groups received a post-administration of the teaching performance checklist at the end of the experiment. It was used to see how the microteaching methodology affected the experimental group's teaching efficiency matched to those of the control group who were taught using the traditional 
approach. In addition, a questionnaire of microteaching attitudes was used and applied on the experimental group subjects before and after the treatment to examine their attitudes about the microteaching technique.

\section{Results}

The following are the results to each question:

1. What is the effect of using the microteaching technique on the teaching performance of Iraqi EFL student teachers?

To check the study's first aim,the "t-test formula" of two independent samples was used (see Table 2).

Table 2. Statistics for the Control and Experimental Groups of the Post-administration of the Teaching Performance Checklist

\begin{tabular}{|c|c|c|c|c|c|c|c|c|}
\hline \multirow[t]{2}{*}{ Variable } & \multirow{2}{*}{ Group } & \multirow{2}{*}{ No. } & \multirow{2}{*}{ Mean } & \multirow{2}{*}{ SD } & \multicolumn{2}{|c|}{ t-value } & \multirow{2}{*}{ d.f } & \multirow{2}{*}{$\begin{array}{l}\text { Level } \\
\text { of sig. }\end{array}$} \\
\hline & & & & & Calculated & Tabulated & & \\
\hline \multirow{2}{*}{$\begin{array}{c}\text { Teaching } \\
\text { Performance }\end{array}$} & Control & 15 & 1.7886 & 0.50245 & \multirow{2}{*}{9.674} & \multirow{2}{*}{1.76131} & \multirow{2}{*}{14} & \multirow{2}{*}{0.000} \\
\hline & Experimental & 15 & 4.0650 & 0.77976 & & & & \\
\hline
\end{tabular}

Table (2) signifies that the experimental group's mean score is (4.0650) and for the control group it is (1.7886). The calculated value (9.674) is higher than the tabulated value (1.76131) at the significance level of 0.000 and 14 freedom degrees. This finding shows a statistically significant difference in teaching performance between the two groups in the post-administration in favor of the experimental group. (See Graphic 1).

Graphic 1. The Post- administration Mean of the Teaching Performance Checklist of the Experimental and Control Groups

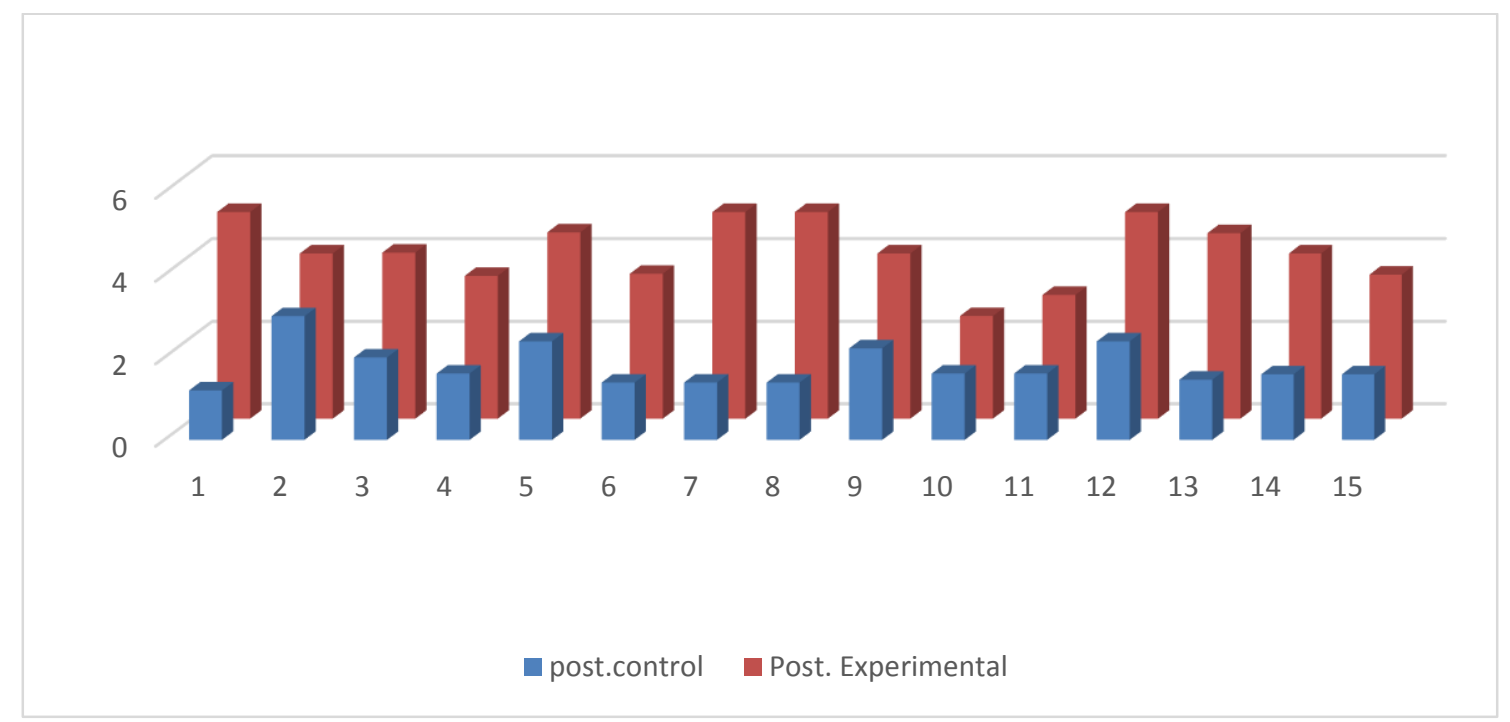

Hence, the first null hypothesis which states that "using the microteaching technique does not significantly affect the teaching performance of Iraqi EFL student teachers"is rejected.

2. What is the effect of using the microteaching technique on Iraqi EFL student teachers' attitudes? 
To investigate the study's second aim ,the "t-test formula" of two independent samples was used (See Table3).

Table 3. The Participants' Attitudes towards Micro teaching in the Pre and Post-administration of the Questionnaire for the experimental Group

\begin{tabular}{|c|c|c|c|c|c|c|c|c|}
\hline \multirow[t]{2}{*}{ Variable } & \multirow{2}{*}{ Group } & \multirow{2}{*}{ No. } & \multirow{2}{*}{ Mean } & \multirow{2}{*}{ SD } & \multicolumn{2}{|c|}{ t-value } & \multirow{2}{*}{ d.f } & \multirow{2}{*}{$\begin{array}{l}\text { Level } \\
\text { of sig. }\end{array}$} \\
\hline & & & & & Calculated & Tabulated & & \\
\hline \multirow{2}{*}{$\begin{array}{l}\text { Teaching } \\
\text { Performance }\end{array}$} & Pre-experimental & 15 & 0.7615 & 0.22199 & \multirow{2}{*}{20.569} & \multirow{2}{*}{1.76131} & \multirow{2}{*}{$` 14$} & \multirow{2}{*}{0.000} \\
\hline & Post-experimental & 15 & 4.3556 & 0.59966 & & & & \\
\hline
\end{tabular}

As shown above, in Table 3, the post-experimental group's mean score is (4.3556) and the pregroup's is $(0.7615)$. The t- calculated value (20.569) is higher than the t- tabulated value (1.76131) at (0.000) significance level and (14) degrees of freedom. This result confirms a statistically significant difference between pre and post administration of the questionnaire for the experimental group in microteaching attitudes in favor of the post-experimental one (See Graphic 2).

Graphic 2. The Participants' Attitudes towards Microteaching in the Pre and Post-administration of the Questionnaire for the experimental Group

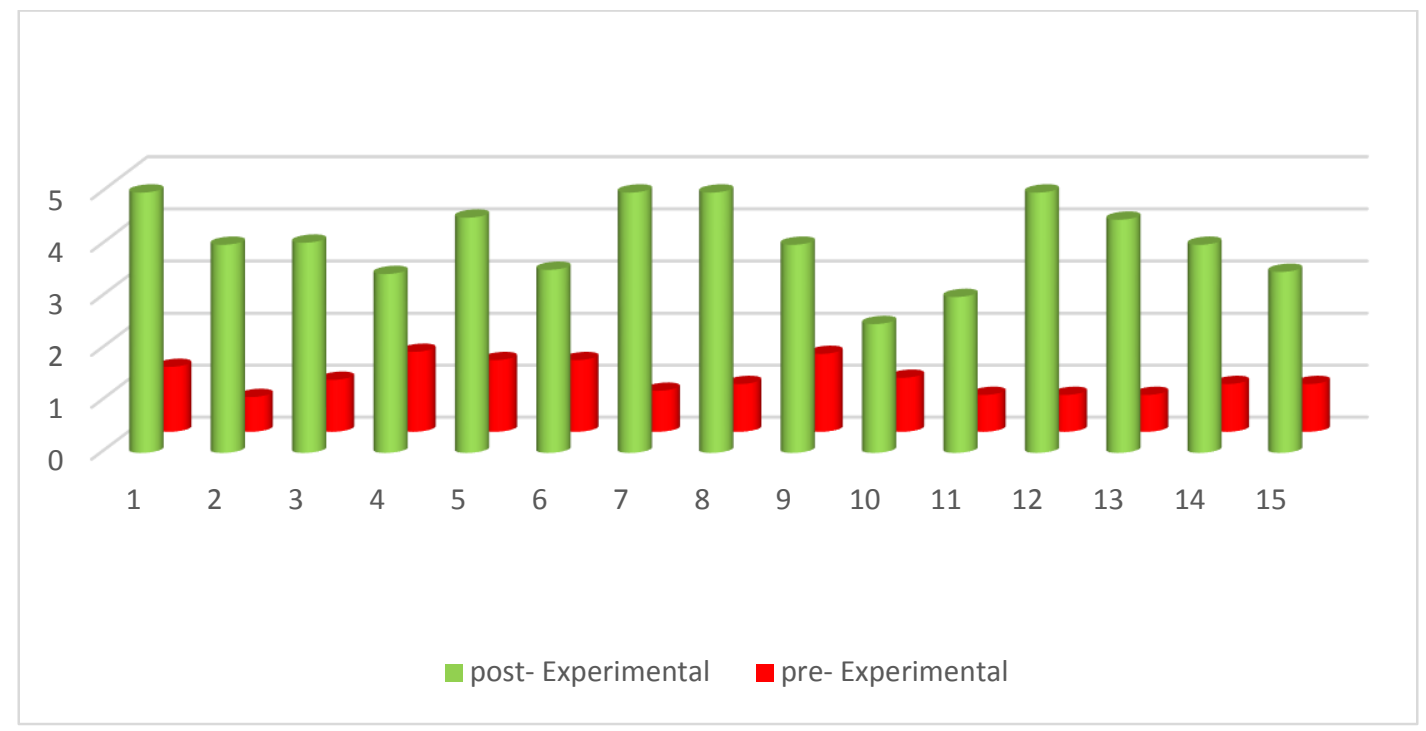

As a result, the second null hypothesis which states that "using the microteaching technique does not significantly affect Iraqi EFL student teachers' attitudes" is also rejected.

\section{Discussion}

The post-test results demonstrate that the output of the experimental group student teachers is much higher than that of the control group, indicating that microteaching is more rewarding than traditional tutoring. This technique allows student instructors to learn and internalize new teaching abilities in a controlled environment., master a variety of teaching skills, gain interest in teaching. The majority of student teachers said that their microteaching experiences affected their education through strengthening their speaking skills, motivation, and questioning proficiency, self-reliance, preparation, and reinforcement ability. These results support those of Ogeyik (2009), Ismail (2011), and Mahmud 
and Rawshon (2013), who found that student teachers' microteaching experiences affect student performance.

\section{Conclusion}

Based on the results attained, the researchers have come up with the following conclusions: The proposed microteaching technique has an important effect on the level of teaching performance of the experiment's participants. The post-administration results reveal a significant statistical differencefor the experimental group that was taught using the proposed microteaching method. Furthermore, the results of the post-administration of the microteaching attitude questionnaire show that the microteaching methodology has a positive impact on EFL learners' attitudes toward microteaching.

\section{References}

Adewoyin, J. A. (2007). Fundamentals of educational technology. Ota: Artitude Communications Inc.

Al-Zaidiyeen, N. J., Mei, L. L. \& Fook, S. F. (2010). Teachers' attitudes and levels of technology use in classrooms: The case of Jordan Schools. International Education Studies, 3(2), 211-218.

Ambili, R. (2013). Microteaching, an efficient technique for learning effective teaching. Journal of Research in Medical Sciences, 18(2), 158-163.

Amobi, F.A. (2005). Preservice teachers'reflectivity on the sequence and consequences of teaching actions in a microteaching experience. Teacher Education Quarterly, 32(1), (115-130).

Ananthakrishnan, N. (1993). Microteaching as a vehicle of teacher training--its advantages and disadvantages. Journal of Postgraduate Medicine, 39(3), 142-143.

Arends, R. I. (2012). Learning to teach. New York: McGraw-Hill.

Barros, S., \& Elia, M. (1998). Physics teachers' attitude: how do they affect the reality of the classroom and models for change?. In Tiberghien, A., Jossem, E. \& Barojas, J. (Eds.), Connecting research in physics education with teacher education pp. 86-91. Cambridge: The International Commission on Physics Education.

Bichi, A., Embong, R. \& Mamat, M. (2016). Assessment of postgraduate students attitude and competence in the use of ICT: A case of Nigerian students at the Universiti Sultan Zainal

Abidin, Malaysia. In: International Postgraduate Research Conference, 08-10 Oct 2016, Terengganu.

Can, V. (2009). A Microteaching application on a teaching practice course. Cypriot Journal of Educational Sciences, 4, 125-140.

Çelik, Ş. (2001). The attitudes of thestudent teachers towards microteaching technique as a tool for reflectionin a teacher education programme. [Master's thesis, Bursa Uludağ University].

Dweikat, K.A. (2010). Investigating attitudes of ELT (2) learners towards microteaching. First National Conference on: "Improving TEFL Methods \& Practices at Palestinian Universities", Palestine. Retrieved from:http://search.shamaa.org/FullRecord?ID=81296.PDF.

Eksi, G. (2012). Implementing an observation and feedback form for more effective feedback in microteaching. Education and Science, 37(164), 267-282.

Feldman, J. (2003). The simplicity principle in human concept learning. Current Directions in Psychological Science, 12(6), 227-232. 
Fernandez, M.\& Robinson, M. (2006). Prospective teachers' perspectives on microteaching lesson study. Education, 127(2), 203-215.

Fernandez, M.(2010). Investigating how and what prospective teachers learn through microteaching lesson study. Teaching and Teacher Education, 26(2), 351-362.

Gorgen, I. (2003). The Effects of microteaching practices on student teachers' views of presenting lessons in the classroom. Hecettepe University Journal of Education, 24, 56-63.

Güney, K. (2008). The Effect of micro- reflective teaching method in accordance with the presentation performance and reflective thinking activities of students teachers.[Doctoral dissertation, Firat University].

Gürses, A., Bayrak, R., Yalçın, M., Açıkyıldız, M., \& Doğar, Ç. (2005). Investigation of effectiveness of microteaching at practicum. Kastamonu Education Journal, 13(1), 1-10.

Jebungei, N. K. (2017). Forms of training support in the development and use of educational media during microteaching in Christian religious education in public universities, Kenya. International Journal of Education and Research, 5(11), 21-32.

Mahmud, I. \& Rawshon, S. (2013). Microteaching to improve teaching method: An Analysis on students' perspectives. Journal of Research \& Method in Education, 1(4), 69-76.

Majoni, C. (2017). Assessing the effectiveness of microteaching during teacher preparation. European Journal of Research and Reflection in Educational Sciences, 5(2), 31-36.

Kpanja, E. (2001). A study of the effects of video tape recording in microteaching training. British Journal of Educational Technology, 32(4), 483-486.

Kuran, K. (2009). The Effect of microteaching on teachers' gaining of knowledge and skills. Mustafa Kemal University Journal of Social Sciences Institute, 6(11), 384- 401.

Liston, D.,Whitcomb, J. \& Borko,H.(2006). Too little or too much: teacher preparation and the first years of teaching. Journal of Teacher Education, 5(4), 351-358.

Mahuta, M. G. (2009). Introduction to the teaching profession for teacher-trainees. Sokoto: Mathi Publisher.

Ogeyik, M. C.(2009). Attitudes of the student teachers in English language teaching programs towards microteaching techniques. English Language Teaching, 2(3), 205-212.

Otsupius, I. A. (2014). Micro-teaching: a technique for effective teaching. African Research Review, 8(4), 183-197.

Owosu, A. A. \& Brown, M. (2014). Teaching practice supervision as quality assurance tool in teacher preparation: views of trainee teachers about supervision in University of Cape Coast. International Journal of Research in Humanities, Arts and Literature, 2, 26-36.

Peker, M. (2009). The use of expanded microteaching for reducing pre-service teachers' teaching anxiety about mathematics. Scientific Research and Essay, 4(9), 872-880.

Ismail, S. (2011). Student teachers' microteaching experiences in a preservice English teacher education program. Journal of Language Teaching and Research, 2(5), 1043-1051.

Sen, A. I. (2009). A study on the effectiveness of peer microteaching in a teacher education program. Education and Science, 34(151), 165-174. 
Suja, K. (2007). Interaction effect of attitude towards teaching, interest in teaching and teaching experience of job commitment of primary school teachers. [Unpublished Master's Thesis]. University of Calicut.

Ustuner, M., Demirtas H., \& Comert, M. (2009). The attitudes of prospective teachers towards the profession of teaching (The case of Inonu University, Faculty of Education). Education and Science, 34(151), 144-155.

\section{AUTHOR BIODATA}

Ali Abdulhussein Sagban is an asst. professor of English at the Department of Material Management Techniques, Technical Institute of Al-Diwaniyah, Al-Furat Al-Awsat Technical University (ATU), Iraq. He got his Ph.D. in Education and Psychology/ Methods of TeachingEnglish as a foreign language at the University of Baghdad in 2014. His major of interest ismethods of teachingEnglish as a foreign language and applied linguistics. He has published eleven articles.

Hisham Adnan Al Mumar is a lecturer of English at the Department of Regional Planning, College of Physical Planning, University of Kufa, Iraq. He got amaster's degree in English language and linguistics at the University of Babylon in 2009. His major of interest is pragmatics andapplied linguistics. He has published eight articles.

Zaid Fouad Hashim is a lecturer of English at the Department of Health Management Techniques, Technical Institute of Al- Diwaniyah, Al-Furat Al-Awsat Technical University (ATU),Iraq. He got amaster's degreein the English language at the University of Bangalore, India in 2013. His major of interest is English literature.

AppendixI

The Teaching Performance Checklist

\begin{tabular}{|c|c|c|c|c|c|c|c|}
\hline No. & Criteria & Items & 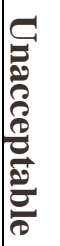 & $\stackrel{0}{\varrho}$ & 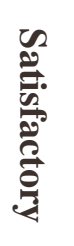 & $\begin{array}{l}\Omega \\
\stackrel{2}{0}\end{array}$ & 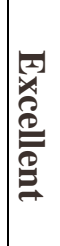 \\
\hline \multirow[t]{4}{*}{1.} & \multirow[t]{4}{*}{$\begin{array}{l}\text { Planning and } \\
\text { Organization }\end{array}$} & $\begin{array}{l}\text { 1. Illustrates clear signs of planning and } \\
\text { organization. }\end{array}$ & & & & & \\
\hline & & 2. Displays a general survey of the lesson. & & & & & \\
\hline & & 3. Step out lesson appropriately. & & & & & \\
\hline & & 4. Shows topics in logical order. & & & & & \\
\hline \multirow[t]{4}{*}{2.} & \multirow[t]{4}{*}{ Learning Objectives } & $\begin{array}{l}\text { 5. Construct measurable and realistic } \\
\text { objectives clearly. }\end{array}$ & & & & & \\
\hline & & $\begin{array}{l}\text { 6. Characterizes the learning objectives for } \\
\text { each instructional activity. }\end{array}$ & & & & & \\
\hline & & $\begin{array}{l}\text { 7. Construct objectives that are closely linked } \\
\text { to the students' needs. }\end{array}$ & & & & & \\
\hline & & 8.Clarifies the lesson's objectives to students. & & & & & \\
\hline \multirow[t]{2}{*}{3.} & \multirow[t]{2}{*}{$\begin{array}{l}\text { Content Knowledge } \\
\text { and Relevance }\end{array}$} & $\begin{array}{l}\text { 9.Presentsthe material at a level that is suitable } \\
\text { for the students. }\end{array}$ & & & & & \\
\hline & & $\begin{array}{l}\text { 10. Demonstrates content that is relevant to the } \\
\text { course's objectives. }\end{array}$ & & & & & \\
\hline
\end{tabular}




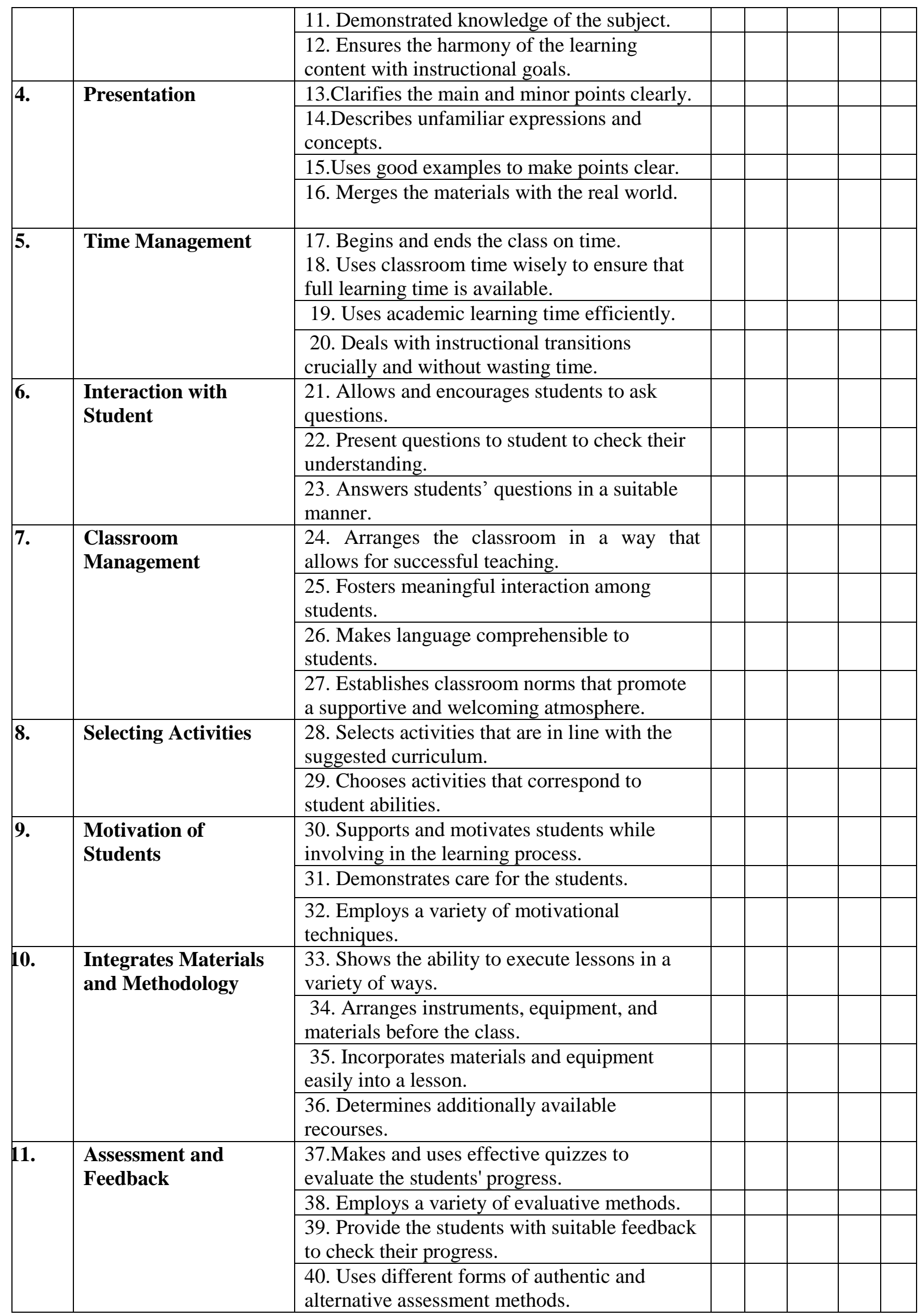




\begin{tabular}{|l|l|l|l|l|l|l|}
\hline & $\begin{array}{l}\text { 41.Provides constructive and motivational } \\
\text { feedback to the students to enhance their } \\
\text { comprehension and progress. }\end{array}$ & & & & \\
\hline
\end{tabular}

Appendix II

The Attitudes toward Microteaching Questionnaire

\begin{tabular}{|c|c|c|c|c|c|c|}
\hline No & Items & 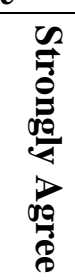 & $\frac{\overrightarrow{8}}{8}$ & $\begin{array}{l}5 \\
\frac{3}{2} \\
\frac{2}{2} \\
\frac{2}{2} \\
2\end{array}$ & 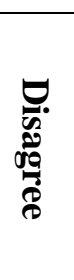 & 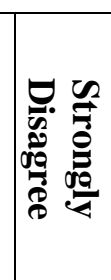 \\
\hline 1. & $\begin{array}{l}\text { Microteaching aids in creation and proper manipulation of } \\
\text { my teaching abilities. }\end{array}$ & & & & & \\
\hline 2. & Microteaching helps me gain faith in my ability to teach. & & & & & \\
\hline 3. & $\begin{array}{l}\text { Microteaching allows me to overcome my fears and } \\
\text { anxieties about teaching. }\end{array}$ & & & & & \\
\hline 4. & $\begin{array}{l}\text { Microteaching helps me to effectively handle classroom } \\
\text { situations. }\end{array}$ & & & & & \\
\hline 5. & $\begin{array}{l}\text { Microteaching assists me in deciding on a teaching target } \\
\text { and creating a lesson plan. }\end{array}$ & & & & & \\
\hline 6. & $\begin{array}{l}\text { Microteaching aids in the development of my capability to } \\
\text { raise questions and talk in front of a group of people. }\end{array}$ & & & & & \\
\hline 7. & $\begin{array}{l}\text { Microteaching improves my ability to choose suitable } \\
\text { instructional resources for the delivery of lessons. }\end{array}$ & & & & & \\
\hline 8. & $\begin{array}{l}\text { Microteaching assists me in successfully managing time in } \\
\text { the classroom. }\end{array}$ & & & & & \\
\hline 9. & $\begin{array}{l}\text { Microteaching makes me more conscious of my teaching } \\
\text { abilities. }\end{array}$ & & & & & \\
\hline 10. & $\begin{array}{l}\text { Microteaching provides me with the ability to hone my } \\
\text { lesson planning skills. }\end{array}$ & & & & & \\
\hline 11. & $\begin{array}{l}\text { Microteaching assists me in honing the actual teaching skills } \\
\text { that I will need in the future. }\end{array}$ & & & & & \\
\hline 12. & $\begin{array}{l}\text { Microteaching allows me to acquire and use new teaching } \\
\text { skills. }\end{array}$ & & & & & \\
\hline 13. & $\begin{array}{l}\text { Microteaching assists me in identifying my strengths and } \\
\text { shortcomings as a teacher. }\end{array}$ & & & & & \\
\hline 14. & Microteaching allows me to observe and learn from others. & & & & & \\
\hline 15. & $\begin{array}{l}\text { Microteaching has made me more conscious of the qualities } \\
\text { that make a good instructor. }\end{array}$ & & & & & \\
\hline 16. & $\begin{array}{l}\text { Microteaching allows me to gain experience with class } \\
\text { management. }\end{array}$ & & & & & \\
\hline 17. & Microteaching helps me to develop independence. & & & & & \\
\hline 18. & $\begin{array}{l}\text { Microteaching aids my learning in time management and } \\
\text { organization. }\end{array}$ & & & & & \\
\hline 19. & $\begin{array}{l}\text { Microteaching helps me to incorporate concepts I've } \\
\text { learned in previous courses. }\end{array}$ & & & & & \\
\hline 20. & $\begin{array}{l}\text { Microteaching allows me to develop my lesson planning } \\
\text { skills. }\end{array}$ & & & & & \\
\hline 21. & Microteaching assists me in writing effective success goals. & & & & & \\
\hline 22. & $\begin{array}{l}\text { Microteaching aids in the creation of instructional materials } \\
\text { and events. }\end{array}$ & & & & & \\
\hline 23. & $\begin{array}{l}\text { Microteaching gives me the courage to speak in front of a } \\
\text { group. }\end{array}$ & & & & & \\
\hline
\end{tabular}




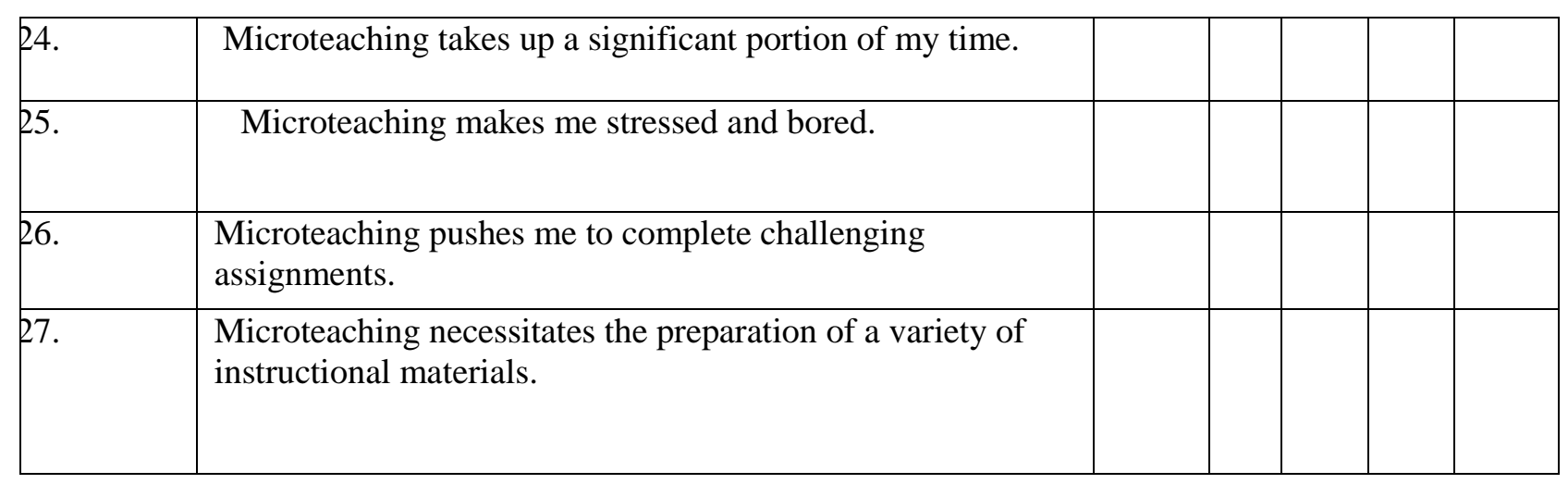

